\title{
PORTRAYING CORONAVIRUS THROUGH METAPHORS IN ONLINE MASS MEDIA HEADLINES
}

\author{
RADEN INDRAJID LUKMAN SARJONO \\ Sanata Dharma University, Yogyakarta, Indonesia \\ lukmanindra02@gmail.com \\ BARLI BRAM \\ Sanata Dharma University, Yogyakarta, Indonesia \\ barli@usd.ac.id
}

\section{DOI: 10.29300/ling.v7i1.4640}

Received: June $5^{\text {th }}, 2021$

Accepted: June $10^{\text {th }}, 2021$

Published: July $14^{\text {th }}, 2021$

\begin{abstract}
Online mass media use metaphors in their headlines to influence the public's minds. Drawing on Lakoff and Johnson's (1980) Conceptual Metaphorical Theory on understanding, this paper aimed to explore the Coronavirus through metaphors in three online mass media headlines. A qualitative approach was used to analyze the data. The data, consisting of 30 headlines concerning Coronavirus, were collected from headlines of three online mass media and then classified and mapped based on the Conceptual Metaphorical Theory. The findings showed that 10 types of metaphors were used in 30 headlines. The two most frequent conceptual metaphors of Coronavirus were Coronavirus as War and Coronavirus as Enemy. The metaphors in online mass media headlines can either bring a negative or positive view toward Coronavirus. Metaphors in online mass media headlines can function as a preventive rhetorical tool to educate people about Coronavirus.
\end{abstract}

Keywords: Conceptual Metaphorical Theory, Coronavirus, mass media headline, metaphor

\section{INTRODUCTION}

COVID-19 (Coronavirus disease 2019), a new type of Coronavirus, known as SARSCoV-2 (severe acute respiratory syndrome coronavirus 2), has been discovered to be the cause of this disease (Chakraborty \& Maity, 2020). The impact of the Coronavirus hits many sectors and elements of human life. Nicola, Alsafi, Sohrabi, Kerwan, Al-Jabir, Iosifidis, Agha, and Agha (2020) also conclude that the Coronavirus significantly affects primary and secondary factors of human life, such as the socio-economic sector. Many online mass media conceptualize the danger of Coronavirus into many pictures. The rapid change in the current situation is the chance of online mass media to bring much news regarding the Coronavirus. The news might steer the public's opinions and perceptions which can lead to negative emotions such as anger, fear, anxiety, and insecurity.

How to cite this article:Sarjono, R., \& Bram, B. (2021). Portraying Coronavirus through Metaphors in Online Mass Media Headlines. Linguists : Journal Of Linguistics and Language Teaching, 7(1), 105-117. doi:http://dx.doi.org/10.29300/ling.v7i1.4640 
It appears that online mass media tend to utilize metaphorical words in affecting readers' perceptions of Coronavirus in their headlines. According to Kövecses (2018), in advertising and other media, the implementation of metaphors will also create new realities that are, of course, described metaphorically for us. Chen (2018) also states that metaphor is most frequently used as a rhetorical device to boost the vividness of expression and efficiency of particular meaning in the news. Those ideas are evidence of the importance of metaphor in media headlines. Furthermore, our perception of the Coronavirus might come into reality in our minds regarding the metaphorical words in online mass media.

The concept of metaphorical words comes from the conceptual metaphorical theory proposed by Lakoff and Johnson (1980). The aim of Conceptual Metaphorical Theory (CMT) is to settle crucial cognitive problems (Lakoff \& Johnson, 1980). It resembles the current conditions in which mass online media affects the readers' perceptions of Coronavirus. Some studies of metaphor in media headlines have been conducted. For example, Sirait, Seva, and Lingga (2020) explored Coronavirus metaphors in Indonesian media headlines, namely The Jakarta Post and Kompas.com, and concluded that there were nine kinds of conceptual metaphors of Coronavirus in the headlines of the two data sources. The most frequent among the nine was conceptualized as Coronavirus is a War. The study revealed that the Coronavirus metaphor was utilized as a reminder to acknowledge the danger of the virus. Pasaribu, Dewi and Bram (2021) conducted a study on metaphors for COVID-19 in the online journal "Thinking Faith". Studies of metaphors in general were also conducted (Jati, 2020; Utami,_Sucianingrum, \& Tapobali, 2019). Kovecses (2010) concluded that metaphors were a valuable tool in comprehending how media delivered messages in their headlines to construct virtual realities.

\section{Cognitive Linguistics Understanding}

How language affects the mind comes from cognitive linguistics. The emphasis in cognitive linguistics is said to be on the assumptions that "language reflects patterns of thought" and that "to study language from this perspective is to study patterns of conceptualization', (Evans \& Green, 2006, p.5). It appears that conceptualization of patterns is in the form of study language. The concept of cognitive linguistics is originated from the work of George Lakoff, Ron Langacker, and Len Talmy in the late 1970s and early 1980s. The work focuses on language tools for information organization, production, and transmission (Geeraerts \& Cuyckens, 2010). Many studies have developed the concept of cognitive linguistics as proposed by Evans and Green (2006). 


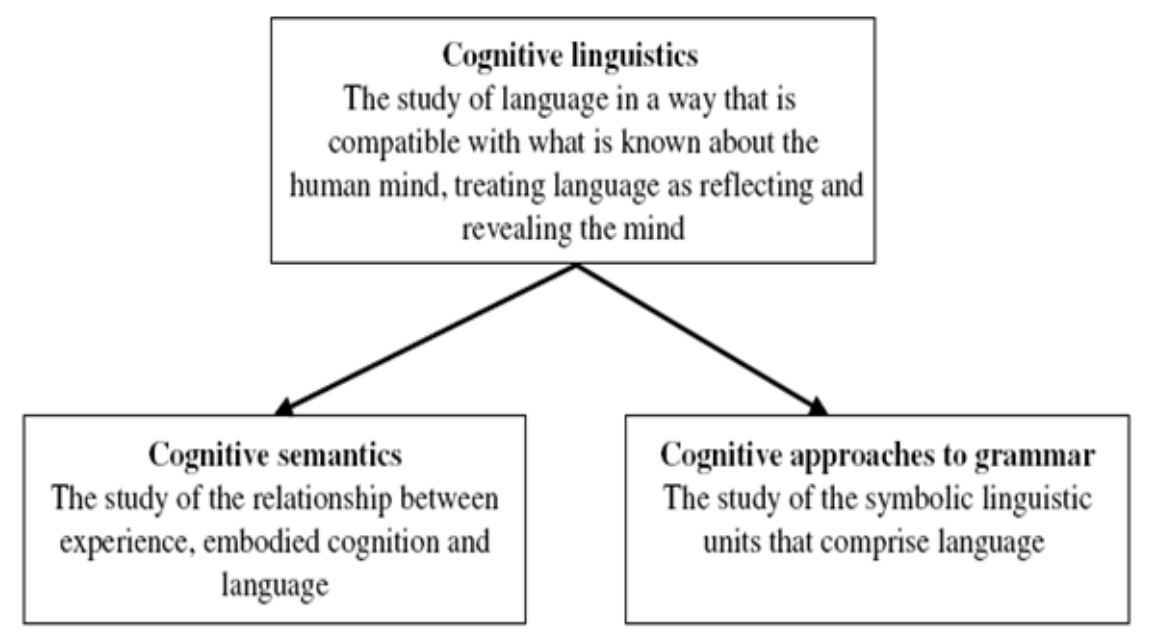

Figure 1. The study of meaning and grammar in cognitive linguistics

The concerns of cognitive semantics and cognitive (approaches to) grammar are indicated in Figure 1. However, cognitive semantics will impact more to comprehend the relation between cognitive linguistics and metaphors. Based on Evans and Green (2006), "cognitive semantics sees linguistic meaning as a manifestation of conceptual structure: the nature and organization of mental representation in all its richness and diversity, and this is what makes it a distinctive approach to linguistic meaning". Furthermore, cognitive semantics holds that language is part of a more general cognitive capacity for humans and can only be explained by the environment as people conceive. It is implicit that there is some difference between this conceptual world and the real world.

\section{Conceptual Metaphorical Theory}

The understanding of metaphors and their impact in online mass media can be drawn from conceptual metaphorical theory. In daily life, metaphors are prevalent, not in language but in thought and action (Lakoff \& Johnson, 1980). It appears that metaphors are already applied daily, such as the use in online mass media.

The central concept of Conceptual Metaphorical Theory (CMT) is how people perceive that an abstract domain is mapped to a source domain, making the abstract definition more comprehensible (Lakoff \& Johnson, 1980). The concepts are known as the source domain (concrete domain) and the target domain (abstract domain). 


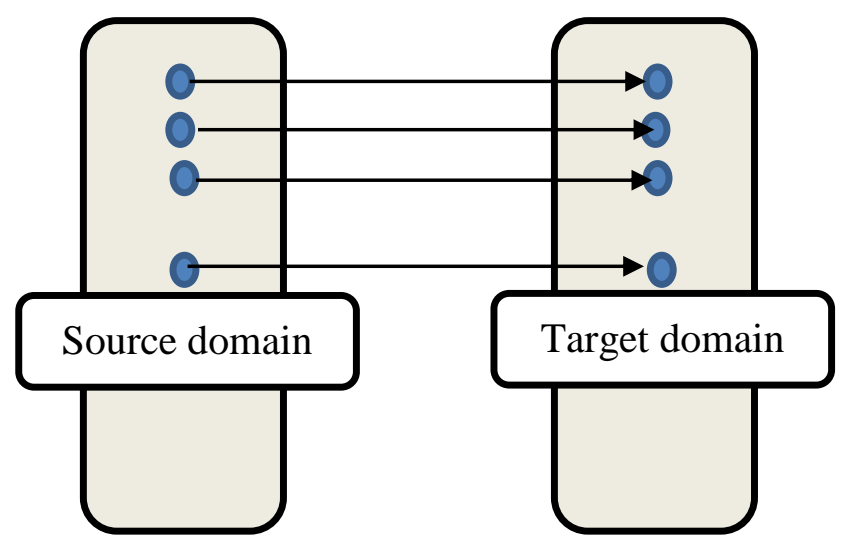

Figure 2. Conceptual mapping

The metaphors work by mapping roles from the source onto the target (source domain onto target domain). Based on Evan and Green (2006), conceptual mappings are one of the significant concerns in cognitive semantics. Moreover, Kovecses (2010) stated that so far, we have used the term "understand" to describe the interaction between two concepts (A and B) in a metaphorical phase. The following shows concept mapping of conceptual metaphorical theory in "Love is Journey" is presented.

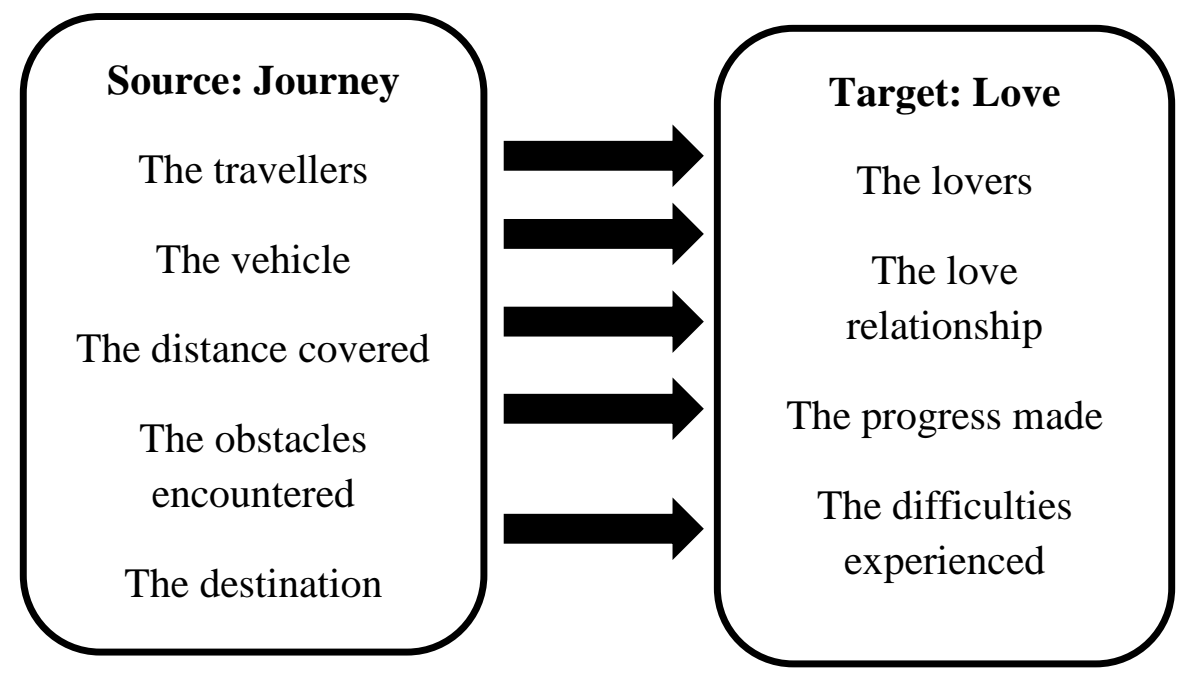

Figure 3. Conceptual mapping of "Love is a Journey"

"Love is a Journey" is a very common metaphor representing journey as a source, and love is a target. The metaphor explains how love is represented as a journey regarding the lovers, progress, difficulties, and goals of the relationship.

In light of the above review, more research is needed to understand the conceptualization of Coronavirus through metaphors in online mass media. Thus, the main focus of this paper is to analyze how online mass media headlines portray the Coronavirus or COVID-19 through metaphors. This study also intended to explore the kinds of conceptual metaphors implemented in the online mass media headlines and the possible intention of the headlines in using the metaphors. 


\section{METHOD}

A qualitative approach was employed in this study since the data gathered and analyzed were non-numerical data. Ary, Jacobs, and Sorensen (2010) state that a qualitative approach is used to analyze the data in the form of words rather than statistic data. Furthermore, this study intends to gather in-depth insights into the use of metaphors in mass online media. The type of research in this study is document analysis since the data is in written form and taken from online mass media. Document analysis focuses on the interpretation of the document, both printed and electronic, regarding obtaining elicit meaning and developing empirical knowledge (Bowen, 2019; Corbin \& Strauss, 2008; Rapley, 2007)

To gather the data, the researchers checked and read some online newspapers, namely The Jakarta Post, The New York Times, and The Guardian. The headlines from the three online newspapers were taken from March to November, comprising Covid-19 metaphors. After that, the data were classified into some categories regarding analyzing the metaphorical words in the headlines. Furthermore, the classifications were mapped based on the conceptual metaphorical theory. Kovecses (2010) states that the basic idea of apprehending the view of metaphor is in the concept of conceptual source domain is the conceptual target domain, which is understandable as a conceptual metaphor.

\section{FINDINGS AND DISCUSSION}

After completing a few steps in collecting the data, some headlines were grouped and classified into the concept of metaphor by applying conceptual metaphorical theory (CMT). The data were taken from forty online newspaper headlines of COVID-19 (coronavirus disease 2019) then further conceptualize into four conceptual metaphorical theories in the following section.

\section{Coronavirus is a War}

The imagery of Coronavirus in war has been used mainly by several online newspapers' headlines. This imagery is one of the most robust representations to describe the impact of Coronavirus on the world. War can be defined as something which only brings tragedy, loss, deaths, sadness, and many more. Nevertheless, the purpose of using this imagery does not merely bring chaos and panic but to remind and convince people of the danger of Coronavirus. Therefore, people will not underestimate and can fight the impact of Coronavirus together.

The metaphor of war is utilized due to the resemblance of the world situation during the havoc wartime to make the metaphor of war engaging at the moment. For instance, there were some "war" metaphors in some headlines, namely enemy, weapon, battling, fight, and Linguists: Journal of Linguistics and Language Teaching Vol. 7, No. 1, July 2021 
COVID-19 fatigue. The "weapon" metaphor is defined by the tools, devices, or even strategies in dealing with Coronavirus. The words "battling" and "fight" are metaphors for the actions and process of defeating Coronavirus, such as both equipping the medical personnel with required protective gear and comprehending them with prudent strategies.

Headlines:

Datum 1: Nurses Battling Coronavirus Beg for Protective Gear and Better Planning

Datum 2: Taiwan's Weapon Against Coronavirus: An Epidemiologist as Vice President

Datum 3: How to fight 'Covid fatigue' as America heads for a deadly winter

Sources: https://www.nytimes.com/ \& https://www.theguardian.com/international

Table 1. Conceptual mapping of Coronavirus is a War

\begin{tabular}{lcl}
\hline Source Domain "War" & Mapping & Target Domain "Coronavirus" \\
\hline Enemy & $\rightarrow$ & Coronavirus \\
Weapon & $\rightarrow$ & Tools to fight Coronavirus \\
Battling & $\rightarrow$ & The process of defeating Coronavirus \\
Fight & $\rightarrow$ & The actions of defeating Coronavirus \\
Covid fatigue & $\rightarrow$ & One of the impacts of Coronavirus \\
\hline
\end{tabular}

\section{Coronavirus is a War of Economy}

This metaphor intends to describe the Coronavirus impacts on the world's economic state. The havoc caused by Coronavirus extremely hit the world's economy. It is shown by many headlines focused on the economic issue. Taken from four headlines in two newspaper agencies, Coronavirus is conceptualized into several representations, namely enemy, battlegrounds, heroes, economy, and recovery. The "battlegrounds" concept is explicitly used to show the economic challenge encountered by a particular nation.

The representation of "Heroes" is also present in one of the provided headlines as the idea of economic experts. The "heroes" metaphor is meant to bring people's morale up to fight Coronavirus in economic sections as there is the presence of economic experts on their side.

Datum 4: In Midwest Battlegrounds, the Virus Met Another Concern: The Economy

Datum 5: Explainer: Indonesia to finance coronavirus battle mostly through debt

Datum 6: Economic heroes in time of Coronavirus

Datum 7: Rising US weekly jobless claims, COVID-19 cases point to slowing economic recovery

Sources: https://www.nytimes.com/ \& https://www.thejakartapost.com/ 
Table 2. Conceptual mapping of Coronavirus is a War of Economy

\begin{tabular}{lcl}
\hline $\begin{array}{l}\text { Source Domain } \\
\text { "War of Economy" }\end{array}$ & Mapping & Target Domain "Coronavirus" \\
\hline Enemy & $\rightarrow$ & Coronavirus \\
Economy & $\rightarrow$ & Things or placed demolished \\
Battlegrounds & $\rightarrow$ & The place struggled with Coronavirus \\
Heroes & $\rightarrow$ & Economic experts \\
Recovery & $\rightarrow$ & Process of regaining possessions of economy \\
\hline
\end{tabular}

\section{Coronavirus is an Enemy (Five Subtypes)}

Enemy is mainly defined as someone or something that needs to be defeat. Winning is imperative if we are dealing with an enemy. Some media headlines bring the metaphorical representation into account. The Coronavirus is portrayed as an enemy in distinct ways and fields, as follows:

\subsection{Coronavirus is an Enemy}

Datum 8: Cities are crucial to fighting the coronavirus pandemic

Datum 9: These Lab Animals Will Help Fight Coronavirus

Datum 10: 'A Christmas not like others': Europe wrestles with festive Covid rules

Sources: https://www.thejakartapost.com/, https://www.theguardian.com/international \& https://www.nytimes.com/

Table 3. Conceptual mapping of Coronavirus is an Enemy

\begin{tabular}{lcl}
\hline Source Domain "Enemy" & Mapping & Target Domain "Coronavirus" \\
\hline Enemy & $\rightarrow$ & Coronavirus \\
Fight & $\rightarrow$ & Process and actions of defeating Coronavirus \\
Wrestle & $\rightarrow$ & Struggling of dealing with Coronavirus \\
\hline
\end{tabular}

These headlines depict the Coronavirus as an enemy to be defeated. The metaphorical world of "fight" portrays the process and actions taken by people to demolish Coronavirus. Many steps were taken into consideration to fully wipe the Coronavirus out. However, some nations also still struggle in dealing with Coronavirus, as represent in the "wrestle" metaphor. The headlines show that defeating Coronavirus is a significant matter to all of the people; even the struggles are real.

\subsection{Coronavirus is an Educational Enemy}

Datum 11: Jokowi calls for patience as schools remain closed amid virus concerns

Datum 12: Schools in England struggle to stay open as Coronavirus hits attendance

Datum 13: Education of poorest pupils in England 'suffers most during Covid isolation'

Sources: https://www.thejakartapost.com/\&https://www.theguardian.com/international Linguists: Journal of Linguistics and Language Teaching Vol. 7, No. 1, July 2021 
Table 4. Conceptual mapping of Coronavirus is an Educational Enemy

\begin{tabular}{lcl}
\hline $\begin{array}{l}\text { Source Domain } \\
\text { "Educational Enemy" }\end{array}$ & Mapping & Target Domain "Coronavirus" \\
\hline Enemy & $\rightarrow$ & Coronavirus \\
Patience & $\rightarrow$ & The suggested actions of dealing with Coronavirus \\
Struggle & $\rightarrow$ & Affliction caused by Coronavirus in education field \\
Suffer & $\rightarrow$ & Pain caused by Coronavirus \\
\hline
\end{tabular}

The impact of Coronavirus also hits the educational sector, as illustrated by some media headlines. Coronavirus has undoubtedly inhibited the school to open and have a learning process in a class. The condition becomes worse as the impact hits the poorest pupils in a particular nation. The concept is shown by metaphorical words of struggle and suffering caused by Coronavirus. The suggested way in the situation is to stay patient with the condition. Moreover, these headlines emphasize the importance of strategy in overcoming the suffering of the educational sector.

\subsection{Coronavirus is a Medical Enemy}

Datum 14: Sicily asks Cuba to send medics as Italy fights second Covid wave

Datum 15: In Indonesia, Coronavirus floods Cisadane River with extra hazard: Medical waste

Sources: https://www.thejakartapost.com/\&https://www.theguardian.com/international

Table 5. Conceptual mapping of Coronavirus is a Medical Enemy

\begin{tabular}{lcl}
\hline $\begin{array}{l}\text { Source Domain } \\
\text { "Medical Enemy" }\end{array}$ & Mapping & Target Domain "Coronavirus" \\
\hline Enemy & $\rightarrow$ & Coronavirus \\
Fight & $\rightarrow$ & Process and actions of defeating Coronavirus \\
Flood & $\rightarrow$ & The impact caused by Coronavirus \\
\hline
\end{tabular}

Many sectors get the direct impact of Coronavirus includes the prominent sector, which is the medical sector. As mentioned in one of the headlines, medics need to work harder to defeat the coronavirus wave in a particular area. The evidence of Coronavirus' impact has already been shown in these headlines. Many areas struggle with acquiring medics, so they need other nations for help. Moreover, the massive impact of Coronavirus is portrayed by flooding the river with medical waste.

\subsection{Coronavirus is a Nations' Enemy}

Datum 16: Indonesian military deployed for coronavirus fight

Datum 17: Asia battles second wave of Coronavirus with fresh lockdowns 
Datum 18: 'In a war, we draw': Vietnam's artists join fight against Covid-19

Datum 19: Israel's Not-So-Secret Weapon in Coronavirus Fight: The Spies of Mossad

Sources: https://www.thejakartapost.com/, https://www.theguardian.com/international \&

https://www.nytimes.com/

Table 6. Conceptual mapping of Coronavirus is Nation's Enemy

\begin{tabular}{lll}
\hline $\begin{array}{l}\text { Source Domain } \\
\text { "Nation's Enemy" }\end{array}$ & Mapping & Target Domain "Coronavirus" \\
\hline Enemy & $\rightarrow$ & Coronavirus \\
Join Fight & $\rightarrow$ & Process and actions of defeating Coronavirus \\
Asia battles & $\rightarrow$ & Working regions in defeating Coronavirus \\
Nation & $\rightarrow$ & People who have to win against Coronavirus \\
Weapon & $\rightarrow$ & Tools to fight Coronavirus \\
\hline
\end{tabular}

Coronavirus is depicted in these headlines as an enemy of nations since it attacks the nations' sectors. These headlines imply that some nations have to join forces to fight Coronavirus. One of the headlines highlights that countries in Asia need to work together to defeat the second wave of Coronavirus. The battle with Coronavirus is undergone by common people, the military, and even artists. They use a collaborative strategy to attack Coronavirus.

\subsection{Coronavirus is an Enemy of Tourism}

Datum 20: Mount Everest Empties as Covid-19 Strikes Tourism in Nepal

Datum 21: Italy bans entry from 13 countries due to coronavirus fears

Sources: https://www.nytimes.com/ \& https://www.thejakartapost.com/

Table 7. Conceptual mapping of Coronavirus is an Enemy of Tourism

\begin{tabular}{lcl}
\hline $\begin{array}{l}\text { Source Domain } \\
\text { "Enemy of Tourism" }\end{array}$ & Mapping & Target Domain "Coronavirus" \\
\hline Enemy & $\rightarrow$ & Coronavirus \\
Strike & $\rightarrow$ & The attack of Coronavirus \\
Tourism & $\rightarrow$ & An impacted field caused by Coronavirus \\
Ban & $\rightarrow$ & The action taken to fight Coronavirus \\
Fears & $\rightarrow$ & An impact caused by Coronavirus \\
\hline
\end{tabular}

These headlines portray the impact of Coronavirus on tourism. This sector gets the effects by forcing the government to regulate closing the tourism areas during coronavirus outbreak. The result can generate a chain-effect to another sector, such as the economic sector. The strike and fear metaphors are used to depict the attack and impact of Coronavirus on tourism. 


\section{Coronavirus is a Fierce Animal}

Datum 22: Zambia's default fuels fears of African 'debt tsunami' as Covid impact bites

Datum 23: Donald Trump appears to admit Covid is 'running wild' in the US

Datum 24: Republican officials finally forced into action on Covid-19 as reality bites

Sources: https://www.thejakartapost.com/ \& https://www.theguardian.com/international

Table 8. Conceptual mapping of Coronavirus is a Fierce Animal

\begin{tabular}{lcl}
\hline $\begin{array}{l}\text { Source Domain } \\
\text { "Fierce Animal" }\end{array}$ & Mapping & Target Domain "Coronavirus" \\
\hline Fierce Animal & $\rightarrow$ & Coronavirus \\
Bite & $\rightarrow$ & The wildness of Coronavirus \\
Running wild & $\rightarrow$ & Coronavirus' impacts cannot be controlled \\
\hline
\end{tabular}

The concept of fierce animals in these headlines is to comprehend the target domain as the wildness and fierceness of Coronavirus. The word "bite" is used to represent the nature or habit of fierce animals when dealing with their prey. It is implied that coronavirus has hurt and harmed people with its attack. People suffered from Coronavirus as the representation of prey in metaphorical ways.

\section{Coronavirus is a Cruel Natural Phenomena}

Datum 25: Symptomless and spreading, S. Korea battles surge in silent COVID-19 cases Datum 26: US coronavirus cases near 200,000 a day as catastrophic crisis hits new heights Datum 27: Jakarta, a coronavirus epicenter in Indonesia, braces for quarantine Sources: https://www.thejakartapost.com/

Table 9. Conceptual Mapping of Coronavirus is a Cruel Natural Phenomena

\begin{tabular}{lcl}
\hline $\begin{array}{l}\text { Source Domain "Cruel } \\
\text { Natural Phenomena" }\end{array}$ & Mapping & Target Domain "Coronavirus" \\
\hline Cruel natural phenomenon & $\rightarrow$ & Coronavirus \\
Surge & $\rightarrow$ & The rise of Coronavirus case \\
Catastrophic & $\rightarrow$ & $\begin{array}{l}\text { The disastrous impact caused by } \\
\text { Coronavirus }\end{array}$ \\
Epicenter & $\rightarrow$ & $\begin{array}{l}\text { The central location of } \\
\text { Coronavirus crisis }\end{array}$ \\
\hline
\end{tabular}

The disastrous impact caused by Coronavirus has forced people into a chaotic situation. The conditions drive some headlines to portray coronavirus negatively. It can be proven from the provided headlines, which highlight and resemble the coronavirus as a cruel natural phenomenon. The word "surge" is represented as the explosion of coronavirus cases. 
Surge can be defined as a sudden rise in an excessive or abnormal value that is mostly found in natural phenomena. Another headline also illustrates coronavirus as a "catastrophic" crisis that attacks nations. Furthermore, the metaphor of "epicenter" is present in a headline regarding the central location of the coronavirus crisis. Based on the news, Jakarta is the central crisis of coronavirus in Indonesia.

\section{Coronavirus is a Teacher}

Datum 28: What the coronavirus has taught us

Datum 29: Coronavirus boosts community spirit and nationalism

Datum 30: Indonesians abroad share lessons learned from other countries' COVID-19 responses

Source: https://www.thejakartapost.com/

Table 10. Conceptual mapping of Coronavirus is a Teacher

\begin{tabular}{lcl}
\hline Source Domain "Teacher" & Mapping & Target Domain "Coronavirus" \\
\hline Teacher & $\rightarrow$ & Coronavirus \\
Community spirit and & $\rightarrow$ & The learning lesson from \\
nationalism & & Coronavirus crisis \\
Lesson & $\rightarrow$ & Insight from Coronavirus crisis \\
\hline
\end{tabular}

The coronavirus crisis unexpectedly drives several lessons to people. As reported by some headlines, coronavirus is depicted as a teacher for people in a crisis condition. Some headlines particularly highlight the lessons gained from coronavirus. Those lessons are started by preserving our environment and providing a chance to unite with others. The environment begins to heal by spending many decades harmed by humans.

People learn to unite with others intensively to fight coronavirus. Furthermore, coronavirus prompts more people to join social organizations and communities. The condition leads many people to be a bit less selfish. The Spirit of nationalism also gets the impact of the rise of people's trust toward government. Those lessons are evident that coronavirus also encourages some significant lessons in people's lives.

\section{CONCLUSION}

The metaphors in headlines have been widely used as a rhetorical tool to affect people's views toward a particular issue. Some provided headlines in this study also implement metaphors to emphasize the danger of Coronavirus. Nowadays, Coronavirus is undoubtedly murderous to people's lives, as portrayed by the online mass media headlines. Moreover, the representation of Coronavirus in media headlines has negatively affected people's lives to raise their worry and fright of the danger of the virus.

Linguists: Journal of Linguistics and Language Teaching Vol. 7, No. 1, July 2021 
This study identified ten kinds of conceptual metaphors in 30 headlines of online mass media or newspapers, namely Coronavirus is a War, Coronavirus is a War of Economy, Coronavirus is an Enemy, Coronavirus is an Educational Enemy, Coronavirus is a Medical Enemy, Coronavirus is Nations' Enemy, Coronavirus is an Enemy of Tourism, Coronavirus is a Fierce Animal, Coronavirus is a Cruel Natural Phenomenon, and Coronavirus is a Teacher. Based on the conceptual mappings of Coronavirus, the three online mass media headlines mostly depict Coronavirus as War and Enemy.

This concept has intensively been portrayed by media headlines to describe the attack of coronavirus. Coronavirus was explained by the cases of death, damage, and terror caused by it. However, the representation of Coronavirus in the mass media headlines increased the negative feelings of some people. They started to feel sad, panic, worry, and even fright. On the other hand, some people positively interpreted the media headlines as a way to convince them not to underestimate coronavirus. They comprehended the danger of coronavirus thoroughly and joined forces together to repel the coronavirus attack. Thus, the metaphors of Coronavirus in the mass media headlines can either raise positive or negative interpretations.

\section{REFERENCES}

Ary, D., Jacobs. L. C., \& Sorensen, C. (2010). Introduction to research in education (8th ed). Belmont, CA: Wadsworth.

Bowen, G. A. (2009). Document analysis as a qualitative research method. Qualitative Research Journal, 9(2), 27-40. doi:10.3316/QRJ0902027

Chakraborty, I., \& Maity, P. (2020). COVID-19 outbreak: Migration, effects on society, global environment, and prevention. Science of the Total Environment. 728. 138882. 10.1016/j.scitotenv.2020.138882

Chen, B. (2018). Metaphors in English news headlines. In 2018 International Symposium on Humanities and Social Sciences, Management and Education Engineering (HSSMEE 2018). Atlantis Press.

Corbin, J. \& Strauss, A. (2008). Basics of qualitative research: Techniques and procedures for developing grounded theory (3rd ed.). Thousand Oaks, CA: Sage.

Evans, V., \& Green, M. (2006). Cognitive linguistics: An introduction. Lawrence Erlbaum Associates Publishers.

Geeraerts, D., \& Cuyckens, H. (2007). The Oxford handbook of cognitive linguistics. Oxford: Oxford University Press.

Jati, L. (2020). Metaphors in Bring Me the Horizon's selected song lyrics. UC Journal: ELT, Linguistics and Literature Journal, 1(1), 37-59. doi: https://doi.org/10.24071/uc.v1i1.2847

Kövecses, Z. (2018). Metaphor in media language and cognition: A perspective from conceptual metaphor theory. Lege Artis. 3. 124-141. 10.2478/lart-2018-0004.

Lakoff, G., \& Johnson, M. (1980). Johnson Metaphors We Live by. Chicago: University of Chicago Press. 
Nicola, M., Alsafi, Z., Sohrabi, C., Kerwan, A., Al-Jabir, A., Iosifidis, C., Agha, M., \& Agha, R. (2020). The socio-economic implications of the coronavirus pandemic (COVID19): A review. International Journal of Surgery, 78, 185-193. https://doi.org/10.1016/j.ijsu.2020.04.018

Pasaribu, T. A., Dewi, N., \& Bram, B. (2021) A Jesuit perspective on metaphors for COVID19 in the online journal "Thinking Faith". Respectus Philologicus, 39(44), 32-45. doi: 10.15388/RESPECTUS.2020.39.44.75.

Rapley, T. (2007). Doing conversation, discourse and document analysis. London: Sage Seva, K., \& Lingga, T. R. (2020). Conceptualizing corona virus metaphor in media headlines: A cognitive semantic approach. English Journal Literacy Utama, 5(1), 278-286.

Utami, T. N., Sucianingrum, P., \& Tapobali, P. M. (2019). The analysis of denotative and connotative meaning of Indonesian sexist metaphors. ELTR Journal, 3(2), 128-135. 